\title{
Analysis on the Structure of Inbound Tourist Source Market in Anhui YU Tong
}

He Yuan Polytechnic, He Yuan, Guangdong, China

Email: 86282557@qq.com

Keywords: Anhui.inbound tourism. tourist source market.structure.

Abstract. Based on the related data of inbound tourism in Anhui from 2006 to 2015, by aid of the Excel software, analyze the structure of inbound tourist source market in Anhui. The result shows that: the numerical value of geographic concentration index of inbound tourism in Anhui is high and the stability is poor as well as the spatial distribution of tourism-generating regions is concentrated, which is adverse to the stable development of inbound tourism market; the main subjects of the inbound tourist source market are foreigners, the proportion of the tourists from Hong Kong, Macau and Taiwan is gradually increasing; Hong Kong, Macau and Taiwan, Korea, Japan and America are the most important inbound tourist source markets in Anhui, therefore, it is needed to adopt measures to promote the stable development of major markets, strengthen the publicity and promotion aiming at other potential countries.

\section{Introduction}

Since the implementation of the reform and opening-up policy, the inbound tourism in Anhui has ushered a good development environment, the inbound tourist arrivals and the foreign exchange earnings from international tourism have been increasing rapidly and constantly, it can be seen from table 1 that the inbound tourist arrivals in Anhui increased by 453.23\% from 803,700 persons in 2006 to 4,446,300 persons in 2015, the foreign exchange earnings from international tourism increased by $651.83 \%$ from 0.301 billion dollars in 2006 to 2.263 billion dollars in 2015 , the development momentum was strong. In order to comprehensively know the development situation of inbound tourism in Anhui, the paper selects nine countries and areas including Hong Kong, Macau and Taiwan, Japan, Korea, Singapore, America, England, France, Germany and Russia as the research objects, based on the related data of Statistical Yearbook of Anhui (2007-2016) and by aid of Excel software, analyzes the structure of inbound tourist source market in Anhui thus to provide basis for inbound tourism in Anhui.

Table 1. The interannual variation of inbound tourist arrivals in Anhui and the foreign exchange earnings from international tourism from 2006 to 2015

\begin{tabular}{|l|l|l|l|l|l|l|l|l|l|l|}
\hline Year & 2006 & 2007 & 2008 & 2009 & 2010 & 2011 & 2012 & 2013 & 2014 & 2015 \\
\hline $\begin{array}{l}\text { Inbound tourist } \\
\text { arrivals } \begin{array}{c}\text { (tens of } \\
\text { thousands of persons) }\end{array}\end{array}$ & 80.37 & 106.43 & 132.09 & 156.16 & 198.42 & 262.87 & 331.47 & 385.5 & 405.06 & 444.63 \\
\hline $\begin{array}{l}\text { Foreign exchange } \\
\text { earnings from } \\
\text { international tourism } \\
(0.1 \text { billion dollars) }\end{array}$ & 3.01 & 4.24 & 4.54 & 5.66 & 8.2 & 11.79 & 15.63 & 17.31 & 19.6 & 22.63 \\
\hline
\end{tabular}

\section{Analysis on the Structure of Inbound Tourist source in Anhui}

Spatial Structure Analysis. The tourism geographers adopt the geographic concentration index to conduct quantitative analysis on the geographic locations of the tourists and spatial distribution thus to reflect the degree of concentration for tourist source market distribution in tourism destinations, represent it with the mathematical formula ${ }^{[1]}$ : 


$$
\mathrm{G}=100 \times \sqrt{\sum_{\mathrm{i}=1}^{\mathrm{n}}\left(\frac{\mathrm{x}_{\mathrm{i}}}{\mathrm{T}}\right)^{2}}
$$

In the formula, $\mathrm{G}$ is geographic concentration index, $\mathrm{X} i$ is the tourist arrivals of $i$ tourism-generating country, $\mathrm{T}$ is the total tourist arrivals of the destination, $\mathrm{n}$ is the total samples of main tourism-generating regions. The smaller the value of $G$ is, the more dispersed the sources of tourism-generating countries are, which is beneficial to the tourism development of the tourism destinations $^{[2]}$.

Based on the Excel software and by aid of the formula, calculate the geographic concentration index $\mathrm{G}$ and draw the corresponding variation diagram of main inbound tourist source markets in Anhui from 2006 to 2015.( Figure 1).

As it can be seen from the figure 1 that the change trend of the geographic concentration index of inbound tourism market in Anhui from 2006 to 2009 was stable with a small fluctuation in the numerical value from 44 to 46 , and then the numerical value had been increasing since 2010 and finally reached to the summit in 2013, and afterwards, the numerical value began to decline rapidly. This trend showed that the numerical value of geographic concentration index of inbound tourism in Anhui was high and the stability was poor, the spatial distribution of the tourism-generating regions was concentrated and the anti-risk capability was weak, which was adverse to the stable development of inbound tourism market, therefore, it was needed to positively expand the newly-emerging market.

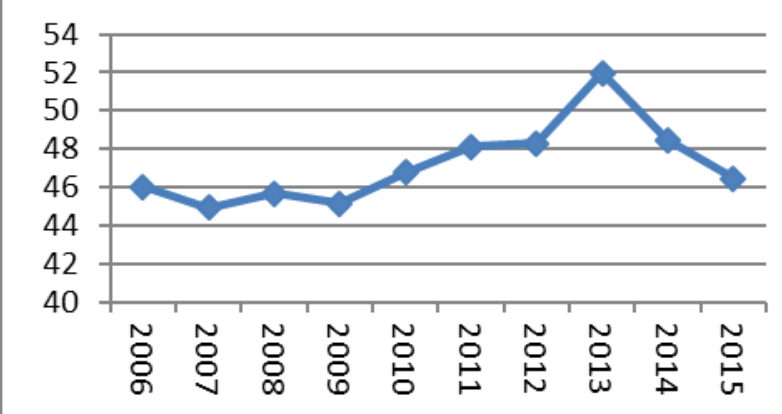

Figure 1 Variation diagram of the geographic concentration index of inbound tourist source market in Anhui

Analysis on the Structure of Inbound Tourist Source. The inbound tourist source market in Anhui consists of two parts, one part are foreigners and the other part are Hong Kong, Macau and Taiwan compatriots.

As it can be seen from table 2 that the foreign tourist arrivals has always been larger than that from Hong Kong, Macau and Taiwan, which are the main subjects of inbound tourists in Anhui with a stable proportion of about $60 \%$, wherein, the proportion was highest of $69.9 \%$ in 2007 . Since 2008 , the proportion had been increasing and reached to the summit of $48 \%$ in 2013 , and afterwards, it declined, but overall presented a rising trend.

Table 2 Types of inbound tourists in Anhui

\begin{tabular}{|c|c|c|c|c|c|c|c|c|c|c|}
\hline Year & 2006 & 2007 & 2008 & 2009 & 2010 & 2011 & 2012 & 2013 & 2014 & 2015 \\
\hline $\begin{array}{l}\text { Foreigners (tens of } \\
\text { thousands of persons) }\end{array}$ & 52.6 & 74.4 & 90.8 & 97.8 & 117.4 & 151.8 & 190.4 & 200.5 & 232.9 & 259.2 \\
\hline Proportion (\%) & 65.4 & 69.9 & 68.7 & 62.6 & 59.2 & 57.7 & 57.4 & 52 & 57.5 & 58.3 \\
\hline $\begin{array}{l}\text { Hong Kong, Macau } \\
\text { and } \\
\text { compatriots (tens of } \\
\text { thousands of persons) }\end{array}$ & 27.8 & 32.1 & 41.3 & 58.4 & 81 & 111.1 & 141.1 & 185 & 172.2 & 185.4 \\
\hline Proportion (\%) & 34.6 & 30.1 & 31.3 & 37.4 & 40.8 & 42.3 & 42.6 & 48 & 42.5 & 41.7 \\
\hline
\end{tabular}

Analysis on the Structure of Tourist Source. As it can be seen from Table 3 and figure 2 that Hong Kong, Macau and Taiwan are the largest region for inbound tourism in Anhui with the average 
occupancy of $41.4 \%$ from 2006 to 2015 . Korea has always been the first largest tourist source country for inbound tourism in Anhui with the average occupancy of $21.7 \%$ and it has a absolute advantage in the inbound tourist arrivals, however, the inbound tourist arrivals in 2015 declined with a year-on-year decrease of $4.47 \%$, which should be paid high attention. America and Japan, as the second and third largest tourist source countries for inbound tourism in Anhui, have the average occupancy of $5.4 \%$ with stable and increasing trend. The ranks of other countries is Singapore, France, Germany, England and Russia with the average occupancy of 2.6\%, 2.4\%, 2.2\%, 2.1\% and $1.2 \%$ respectively. During the period from 2006 to 2015, the inbound tourist arrivals in the main nine inbound tourist source countries and regions in Anhui achieved the growth, wherein, Russia increased most with the proportion of $1743.8 \%$. While Japan increased least with the proportion of 158.6\%. The above analysis shows that Hong Kong, Macau and Taiwan, Korea, Japan and America are the most important inbound tourist source markets in Anhui, therefore,it is needed to adopt measures to promote the stable development of these markets, while other countries occupy a low proportion in the inbound tourist arrivals, but they develop quickly, which are the potential markets in inbound tourism in Anhui,therefore, it is needed to strengthen the publicity and promotion.

Table 3 The inbound tourist arrivals in Anhui from main tourist source markets Unit: tens of thousands of persons

\begin{tabular}{|l|r|r|r|r|r|r|r|r|r|r|}
\hline $\begin{array}{l}\text { tourism-gener } \\
\text { ating region }\end{array}$ & 2006 & 2007 & 2008 & 2009 & 2010 & 2011 & 2012 & 2013 & 2014 & 2015 \\
\hline $\begin{array}{l}\text { Hong Kong, } \\
\text { Macau and } \\
\text { Taiwan }\end{array}$ & 27.78 & 32.08 & 41.28 & 58.41 & 81.02 & 111.12 & 141.06 & 184.98 & 172.16 & 185.44 \\
\hline Japan & 6.71 & 9.18 & 10.88 & 11.29 & 13.53 & 16.16 & 17.11 & 15.18 & 16.51 & 17.35 \\
\hline Korea & 22.73 & 33.32 & 41.56 & 35.96 & 40.55 & 55.17 & 70.01 & 70.23 & 88.05 & 84.11 \\
\hline Singapore & 1.51 & 2.03 & 2.21 & 4.03 & 4.35 & 6.57 & 8.96 & 9.33 & 10.44 & 14.38 \\
\hline America & 4.87 & 6.21 & 7.57 & 8.43 & 10.17 & 13.43 & 17.18 & 22.47 & 23.61 & 21.48 \\
\hline England & 1.14 & 2.44 & 2.98 & 3.69 & 4.91 & 5.87 & 6.45 & 7.54 & 8.11 & 8.56 \\
\hline France & 1.63 & 2.5 & 2.8 & 4.43 & 6.38 & 7.37 & 8.39 & 8.48 & 9.08 & 8.48 \\
\hline Germany & 2.22 & 2.74 & 3.14 & 4.11 & 5.29 & 6.29 & 6.31 & 7.18 & 7.69 & 9.55 \\
\hline Russia & 0.32 & 1.1 & 1.13 & 1.69 & 2.4 & 3.04 & 3.84 & 4.87 & 4.91 & 5.9 \\
\hline
\end{tabular}

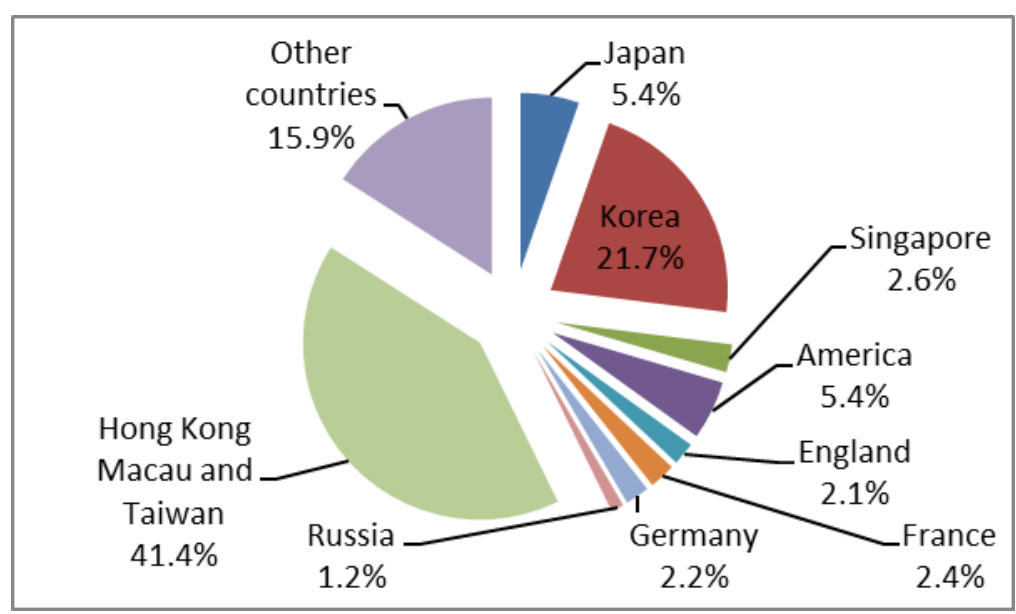

Figure 2 The average occupancy of the inbound tourist source markets in Anhui from 2006 to 2015

\section{Analysis on the Consumption Structure of Inbound Tourists in Anhui}

The consumption structure of inbound tourists consists of two parts including fundamental demand consumption and non-fundamental demand consumption ${ }^{[3]}$, based on the Statistical Yearbook of Anhui, the fundamental demand consumption includes transportation (long-distance transportation 
and urban transportation),tourism, accommodation and catering, the on-fundamental demand consumption consists of commodity sales,entertainment, post and telecommunications communication and other services. As it can be seen from figure 3 , in the average consumption of the inbound tourists in Anhui from 2006 to 2015, the long-distance transportation accounted for the largest proportion of $32.4 \%$ in the total consumption, which showed that if the tourist source countries and regions are far from Anhui, the transportation cost will increase. The commodity sales accounted for $23.5 \%$ with the second place, which had a large difference with the consumption proportion of $40 \%$ of the countries with developed tourismand tended to have a larger promotion space $^{[4]}$. In general, the fundamental demand consumption accounts for $58.6 \%$ and is higher than that of non-fundamental demand consumption, which shows that the consumption structure of inbound tourism in Anhui is reasonable.

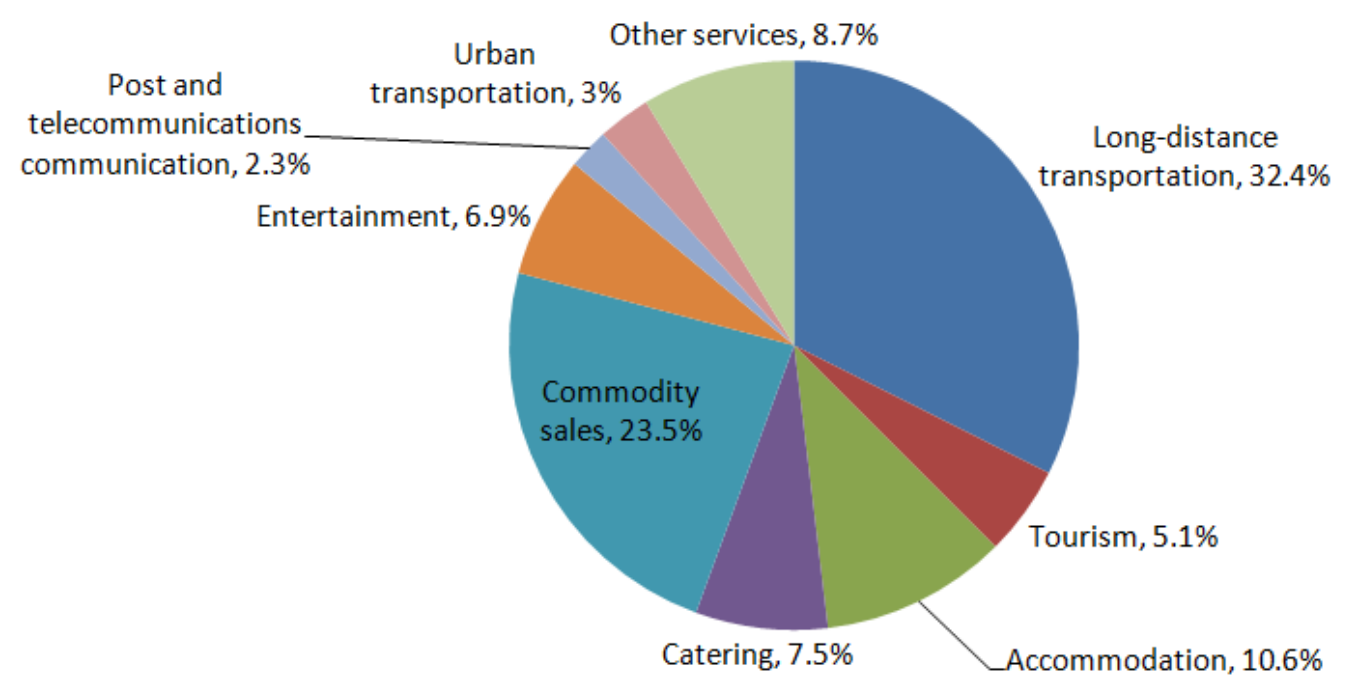

Figure 3 The composition of average consumption of inbound tourist in Anhui

\section{Conclusion}

The numerical value of geographic concentration index of inbound tourism in Anhui is high and the stability is poor as well as the spatial distribution of tourism-generating regions is concentrated and the anti-risk capability is weak, which is adverse to the stable development of inbound tourism market.

The main subjects of the inbound tourist source market are foreigners, the proportion of the tourists from Hong Kong, Macau and Taiwan is gradually increasing; Hong Kong, Macau and Taiwan, Korea, Japan and America are the most important inbound tourist source markets in Anhui, therefore, it is needed to adopt measures to promote the stable development of major markets, strengthen the publicity and promotion aiming at other potential countries.

\section{References:}

[1] Ma Yaofeng, Li Tianshun, Liu Xinping,A Study on the Flowing Pattern of Tourists to China,(China Higher Education Press, China 2001).

[2] Yu Tong, Research on Market Space Changing about Guangdong Source Tourists, Journal of Huizhou University (social science), Vol.34 (2014), p. 36-40.

[3] Ma Yan, Analysis on the structure of inbound tourist source market in Sinkiang, World Regional Studies, Vol.21 (2012), p.160-166.

[4] Shi Zhangyu,Guo Shu, Yu Liyan, Analysis on the basic feature of inbound tourism market in Liaoning, Business Studies, Vol.22 (2006), p.185-189. 